\title{
Consumer Ethnocentrism and Attitudes Towards Foreign Beer Brands: With Evidence from Zlin Region in the Czech Republic
}

\author{
Wanninayake W.M.C.Bandara, Chovancová Miloslava
}

\begin{abstract}
In modern times, consumer ethnocentrism has become an important strategic tool used by domestic firms in the face of global competition. However, the ability to use this phenomenon and its practical validity can vary in different industrial and cultural contexts. Hence, in this study, researchers address this issue by investigating the relationship between consumer ethnocentrism and the attitudes of Czech customers towards foreign beer brands while paying special attention to whether the ethnocentric tendencies of the Czech customers are altered by demographic variables. The sample for this study was drawn from adult customers who live in the Zlin region in the Czech Republic. The group of students from the bachelor degree programme in management and economics, Tomas Bata Universty in Zlin were selected as enumerators for data collection. Altogether 155 questionnaires were distributed and 108 completed questionnaires were taken in for final analysis. The consumer ethnocentric tendency was measured using the famous CETSCALE developed by Shimp and Sharma. Cronbach's Alpha values of each construct confirmed that a good interring reliability exists with the data. Principle component analysis was employed to determine the important factors of CETSCALE and independent $t$ test, correlation analysis, multiple regression analysis and one way ANOVA were used for testing hypotheses. The results revealed that the ethnocentric tendency of consumers is negatively correlated with the favorable attitudes of customers towards foreign beer brands in Czech Republic and also that highly ethnocentric customers hold less favorable attitudes towards foreign brands. Further findings revealed that there are no significant differences between consumer ethnocentrism and all the demographic variables of Czech customers. Finally, the researchers provide some suggestions for domestic brewery firms in the Czech Republic to develop appropriate branding strategies in considering consumer ethnocentrism as a strategic tool.
\end{abstract}

Key words: Consumer Ethnocentrism, Beer Industry, Czech Republic, Consumer Attitudes

\section{INTRODUCTION}

The beer industry of Czech Republic has a long history. According to historical evidence, hops have been cultivated within the country since medieval times (roughly from the10th century onwards) with the help of the perfect agricultural climate in Bohemia. According to historical facts, the first Czech brewery was initially established in 1118 at Cerhenice. Consequently, there were so many milestones that were passed by the Czech brewery industry and at present it has paved way to a unique beer culture combining the Czech language, the Czech culture, and Czech beer into one platform. With the aforesaid background, the brewery industry makes a huge contribution to the Czech economy by making around 830 million Euros value addition 
in terms of production and sales as well as generating approximately 76,000 employment opportunities directly and indirectly. Therefore the growth of the brewery industry has become a crucial point in the national economy of the Czech Republic.

According to the Euromonitor reports 2010, Czech Republic is the highest beer consuming nation per capita in the world (158.6 liters per capita annually). Therefore, Czech Republic by default becomes the most attractive market for beer companies. Currently several leading local brewery companies dominate the beer market of the country. With the emerging full market economy, the Czech brewing industry was privatized in 1997 and most of the foreign investors took over the majority of the brewery companies. However, customers perceive any beer brand as a national brand as long as it has a physical connection to the country (i.e. physically produced within the country's geographic perimeters) and uses a traditional recipe, irrespective of who owns the brand (Siemieniako, Kubacki, Glin'ska \& Krot, 2011). Therefore Czech customers believe all the beer brands produced in Czech Republic as their national brands. On the other hand, both foreign and local brewery companies which are manufacturing within the country make a significant contribution to the national economy of Czech Republic. For instance, national statistics revealed that Czech Republic is currently exporting 2.7 million hectoliters of beer; while importing only 0.2 million hectoliters.

However, global competitors aggressively promote their brands in the domestic market with the purpose of stimulating customers to buy foreign beer brands. The situation has become more serious with the arrival of global hypermarket chains to the Czech Republic. These retail companies make available popular global brands in their stores and attempt to change the inherent beer culture prevalent in Czech. Therefore, the decline in market demand for domestic beer will be a crucial issue to the domestic beer companies in the years to come. Even though some actions can be taken against the arrival of international brands at macro level, most of them are not practically viable due to globalization and the impact of regional trade blocs like the European Union. Therefore, domestic beer companies should use consumer ethnocentrism as a strategic tool to promote local customers to buy domestic brands over foreign counterparts. Further understanding of customer buying motives and developing close relationships with customers have become essential requirements in the today's increasingly crowded marketplace. Thus, understanding customers' attitudes towards foreign brands and to what extent the 'ethnocentric' feelings of customers influence their selection of local brands has become a serious issue that needs to be investigated by researchers. Accordingly, this study reports the ethnocentric tendencies of Czech customers and their evaluation of some attributes of foreign brewery brands available in the domestic market.

The significance and the expected knowledge contribution of this study will veer into three aspects. In general, this study will draw attention to consumer ethnocentrism as an important phenomenon for researching different contexts. It will aim at providing suggestions for further researches. In the theoretical perspective, this study will contribute to developing a comprehensive understanding and application of consumer ethnocentrism in different contexts. In the practical aspect, this study will aim to provide guidelines to marketers of domestic brewery 
companies to develop strategies to stimulate customers to buy Czech beer brands and how to adapt them to the Czech beer culture. In this article the researchers will first discuss the current situation of the Czech beer industry and the theoretical background of related concepts. Then, will continue by presenting the hypotheses and methodology. Discussion of the results will be presented in section five, followed by the conclusion in the final section.

\section{THEORETICAL BACKGROUND AND LITERATURE REVIEW}

\subsection{Consumer Ethnocentrism}

Consumer Ethnocentrism has emerged from the sociological phenomenon called "ethnocentrism" introduced by William G. Sumner in 1906. According to Summer (1906), ethnocentrism is "the technical name for the view of things in which one's own group is the center of everything, and all others are scaled and rated with reference to it". In the other words, ethnocentrism is a tendency of people to believe that their cultural or ethnic group is important and the other groups are evaluated primarily from the perspective of one's own culture. It is further elaborated by Adorno, Frenkel-Brunswik, Levinson \& Sanford (1950) as "ethnic centeredness" and emphasizes this phenomenon as the rigidity in accepting the culturally "alike," while rejecting the culturally "unlike". According to those definitions, a strong ethnocentric person may judge other groups in relation to the cultural dimensions of language, behavior, customs, and religion of his or her own group.

However, researchers of behavioral sciences recognized this concept as a psychological trait that explains the personality system of human beings (e.g. Levine \& Campbell 1972). However, when associated with consumer behavior, it was recognized as "consumer ethnocentrism (CE)" by researchers. Therefore, CE refers to the feelings of consumers that compel them to buy products from their home country and reject foreign-made products (Shimp \& Sharma, 1987). Furthermore, Kaynak \& Kara (2002) noted that CE generates intensions in consumers to buy local products as well as products from the countries that are perceived to resemble their own cultural values. Accordingly, highly ethnocentric individuals are intolerant of cultural differences of other nations and they perceive ethnic and national symbolic values as sources of pride while often despising the values of others (Luque-Martinez, Ibanez-Zapata \& Barrio-Garcia, 2000). According to Shimp \& Sharma (1987) highly ethnocentric consumers perceive that purchasing foreign-made products is wrong due to the damage it causes to the local economy, i.e. creating unemployment, which plainly labels them as unpatriotic.

\subsection{Attitudes toward Foreign Products}

Product attitude is commonly defined as "consumers' overall evaluative judgment of a product's attributes such as style, brand, and quality" (Erdogan \& Uzkurt, 2010). Most of a brand's characteristics are associated with its country of origin (COO). According to Kaynak \& Kara (2002), since the customers evaluate products based on all the information available to them, even though such information is very little- the country of origin becomes a critical determinant of consumer's product evaluation. Furthermore, Huddleston, Linda \& Lesli (2001), noted that the $\mathrm{COO}$ indicates the quality of products based on intrinsic (style, material) and extrinsic (price and brands) cues. Furthermore, Lantz \& Loeb (1996) explored that the COO is more important than the brand name, price, and quality -in shaping attitudes towards the particular 
product. However, some researchers argue that domestic customers may develop favorable altitudes towards the products that come from countries with similar cultural, political and economic conditions (e.g. Kaynak \& Cavusgil, 1983). Furthermore, consumers perceive that products manufactured in developed countries are of a high quality (Huddleston, Linda \& Lesli, 2001). As the present study focuses on the beer industry in the Czech Republic, it can be argued that the $\mathrm{COO}$ of imported beer brands should be considered as a primary factor in assessing the attitudes towards foreign beer brands. However, the imported beer brands in Czech Republic mostly represent eastern European countries where exists similar socio-cultural backgrounds. Therefore the researchers reasonably assume that the Czech customers may not feel considerable differences of $\mathrm{COO}$ among foreign beer brands which are imported from other European countries. However, some researchers (e.g. Akaah \& Yaprak, 1993; Klenosky, Benet \& Chatraba, 1996) have attempted to develop measurement standards to identify to what extent customers value extrinsic and intrinsic cues of domestic brands compared to foreign alternatives. Most of the previous studies were conducted in different contexts and industries. Therefore most of the findings cannot be generalized to the present research context.

\subsection{Consequences of consumer ethnocentrism}

Consequences of consumer ethnocentrism can be analyzed based on direct effect, mediating effect and moderating effect. As per the theoretical background, direct effect of CE is to stimulate customers to purchase domestic products as opposed to foreign products. However, previous researchers have explored that direct impact can be assessed in different formats such as purchasing intention to buy local products (Shimp \& Sharma, 1987), attitudes towards buying local products (Huddleston et al., 2001) and acceptance of local buying campaigns (Shimp \& Sharma, 1987), local brand biasness (Huddleston et al., 2001), brand preference, attitudes towards place of origin (Siemieniako, Kubacki, Glin'ska, \& Krot 2011), brand equity (Shamindra \& Datta, 2011) etc. However, Shankarmahesh (2006) suggested 03 aspects of direct consequences of $\mathrm{CE}$ based on an extensive literature review. According to him, the main categories of consequences are: attitudes towards foreign products, purchasing intention and support for foreign products. Even though most research findings implied that CE has a direct positive relationship with the aforesaid outcomes, the degree of $\mathrm{CE}$ and its impact on consumer behavior can be varied in different contexts. For instance, some researchers from China (Klein, Ettenson \& Krishnan, 2006), Hungary (Papadopoulos, Heslop \& Beracs, 1990) and Russia (Klein \& Ettenson, 1999; Ettenson, Wagner \& Gaeth, 1988), show that customers perceive that foreign products are better than locally-made products. However, some studies in European countries like Poland and Slovakia have found that customers frequently buy domestic brands over foreign brands (Damisch, 1995). Furthermore, Gibbs and Bouszak (1995) argued that Slovakian consumers do not perceive products offered by developed countries to be of a higher quality. Additionally, Shankarmahesh (2006) has suggested that perceived equity, empathy, perceived cost, responsibility, country of origin (COC) and product evaluation as mediating variables between $\mathrm{CE}$ and its outcomes. In addition to the direct outcomes of $\mathrm{CE}$ and mediating variables, consequences can occur through moderating factors between $\mathrm{CE}$ and intentions to buy local products. Moreover, he has suggested 03 main variables such as, perceived product necessity, perceived economic threat and cultural similarity as mediating factors. Furthermore, most 
previous researchers attempted to explore the impact of demographic variables on consumer ethnocentric tendencies. Mainly -age, income, education, race and social class are considered as demographic antecedents of CE (e.g. McLain \& Sternquist, 1991). However the validity of those moderating and mediating variables as well as demographic antecedents may be relatively different in respect to the Czech beer industry. Therefore the most important argument is whether CE can really influence the attitudes of Czech customers towards foreign beer brands in real buying situations.

\section{HYPOTHESES OF THE STUDY}

The main purpose of the present study is to examine the relationship between consumer ethnocentrism and the attitudes towards foreign beer brands of Czech customers and to investigate whether ethnocentric tendencies and consumer attitudes vary by demographic variables. Therefore the researchers have developed several hypotheses to demonstrate the relationship among CE, attitudes towards foreign brands and demographic variables.

Previous studies have shown that ethnocentric tendencies reduce consumers' intentions to purchase foreign goods (Klein et al., 2006; Kwak, Jaju \& Larson, 2006; Vida, Dmitrovic' \& Obadia, 2008). Therefore previous researchers have empirically proved that CE and attitudes towards products show significant relationships (e.g. Sharma, Shimp \& Shin, 1995). Furthermore, consumer ethnocentrism appears to be a strong determinant of general attitudes towards foreign products in relation to domestic products (Biljana \& Anthony, 1998). According to Shimp \& Sharma (1987) highly ethnocentric customers negatively evaluated imported products due to its negative impact on the domestic economy. They further argued that not so strong ethnocentric customers show a favorable attitude towards imported products just because of its foreign origin. Furthermore, highly ethnocentric customers do not make purchasing decisions based on perceived brand globalness compared to not so strong ethnocentric customers (Akram, Merunka \& Akram, 2011). According to Lee, Hong \& Lee (2003), CE is used by customers as predict judgments of the quality of foreign products. Generally, highly ethnocentric customers are motivated to buy domestic products even if they know the quality of the products is lower than the imported alternatives. Moreover, those consumers perceived that foreign products are of a lower quality (Netemeyer, Richard, Durvasula, Lichtenstein \& Donald, 1991). Furthermore, Supphellen \& Grønhaug (2003) noted that highly ethnocentric customers are not motivated to learn about the attributes of foreign brands. A study conducted in Sri Lanka revealed that the ethnocentric values may not be significant in the actual purchasing behavior of customers. Therefore, the ethnocentric values of brands would greatly affect customer awareness building and recalling power only (Wanninayake and Dissanayake, 2009). Furthermore, Juric et al., (1995) have found that consumer ethnocentrism accounted for a small but significant proportion of purchasing behavior. According to the preceding discussion, most of the studies have revealed that higher the ethnocentric tendency, the more negative the attitudes towards foreign or imported brands will be, and thus more positive they are towards domestic products. Accordingly, it is hypothesized that: 
H1. The Consumer ethnocentric tendency in Czech consumers is negatively associated with favorable attitudes towards foreign beer brands.

H2. Czech consumers exhibiting high levels of ethnocentrism will have less favorable attitudes towards foreign beer brands.

Many previous researchers attempted to investigate the impact of demographic variables on CE. According to the Shankarmahesh (2006); age, income, education, race and social class are considered as demographic antecedents of CE. Some studies reveal that CE correlates with age positively, but negatively with education level (McLain \& Sternquist, 1991; Caruana \& Magri, 1996). According to Shimp \& Sharma (1987), there is no relationship between CE and gender or marital status. Furthermore, senior citizens are more ethnocentric than the youth because of their conservative nature (Vida \& Fairhurst, 1999). According to Balabanis, Diamantopoulos, Mueller \& Melewar (2001), well-off educated customers are less ethnocentric and highly motivated to buy imported products. Moreover, some studies reveal that women seem to be more ethnocentric than men (Balabanis et al., 2001, Javalgi, Khare, Gross \& Scherer, 2005). Watson \& Wright (2000) have found that high-ethnocentric consumers are more likely to be female, older, less educated, and less wealthy- than low-ethnocentric consumers.

Furthermore, some studies reveal that there exists a significant relationship between demographic variables and attitudes towards products. For instance, Good \& Huddleston (1995) noted that older customers have negative attitudes towards foreign products. Furthermore, Sajdakowska (2003) argued that price, taste and healthiness of products are more importantirrespective of age, gender and education in developing attitudes towards foreign brands. They further emphasize that educated customers maintain favorable attitudes towards foreign brands. According to Wall \& Heslop (1986), the income level of customers positively correlates with the favorable attitude towards foreign products. Moreover, Schooler (1971) argues that males have more positive attitudes towards domestic brands than female customers.

Based on the preceding discussion, researchers have formed $\mathrm{H} 3$ to determine the relationship between demographic variables and the CE of Czech customers.

H3: There is a significant relationship between age, gender, income and education (demographic characteristics) of Czech consumers and their degree of ethnocentrism.

\section{RESEARCH METHOD}

The respondents of this study were adult customers who live in the Zlin region of the Czech Republic. They were selected based on the convenient sampling method, mainly through the students of Tomas Bata University in Zlin. The students of marketing research course of the bachelor degree programme in management and economics were selected as enumerators for data collection. They collected data through self administrated questionnaires from the adult customers in Zlin region. Altogether 155 questionnaires were distributed and 108 completed questionnaires were taken into the final analysis. The sample consisted of a higher proportion of female respondents (56.3 percent) than male respondents (43.7 percent). In addition, 41.6 percent of the customers were students and 52.8 percent of the customers held graduate and post graduate qualifications. As per the age distribution, the majority of respondents (49.8 
percent) were aged between 31 - 50 years. Therefore the demographic structure of the sample was sufficient to examine the research issue of the given context.

This study's survey instruments were developed based on previous studies. CETSCALE developed by Shimp \& Sharma (1987), was used to measure the respondents' ethnocentric tendency with some modifications to fit the Czech context. This scale has been validated by different studies in different countries like USA, France, Japan, West Germany, Korea, and Poland etc. In all the previous studies it has reported a Cronbach's alpha value of over 0.90 as an indicator of the reliability of the scale (Netemeyer et al., 1991; Sharma et al., 1995; Good and Huddleston, 1995; Huddleston et al., 2001). Some researchers noted that the scale demonstrates both the discriminant and nomological validity as well (e.g. Netemeyer et al., 1991).

Attitudes towards foreign beer brands were assessed in terms of price, quality, taste, aroma, alcohol containment and the impact on health. Those dimensions were selected from previous studies and reports on the beer industry. Customer evaluations of foreign brands commonly under each dimension were aggregated to decide the overall attitudes towards foreign brands. All the scales were scored on a five point likert scale ranging from 1 (strongly disagree) to 5 (strongly agree). Furthermore, the questionnaire included close-ended questions for collecting demographic data, such as age, gender, monthly income, and educational level of the respondents.

\section{RESULTS}

The IBM SPSS 19 package was employed for data analysis. The outcome of the analysis is reported in the first part of this section. Further findings and their possible consequences are also discussed here in detail. Initially, a reliability analysis was done to measure internal consistencies of the total scores for each scale through Cronbach's Alpha Coefficients. The calculation of reliability measurements is presented in table 1 . As per the findings, all the reliabilities for both the scales are found to be adequate since Cronbach's Alpha values are higher than 0.7 (According to George and Mallery (2003), Cronbach Alpha $>.9$ - Excellent, _ $>.8$ - Good, $>.7$ - Acceptable,_ $>.6$ - Questionable, _ $>.5$ - Poor, and $<.5$ - Unacceptable)

Tab. 1 - Reliability analysis for the Scale. Source: Survey data 2011

\begin{tabular}{|c|c|c|c|c|}
\hline Scales & $\begin{array}{c}\text { No. of } \\
\text { Items }\end{array}$ & $\begin{array}{c}\text { Cronbach's } \\
\text { Alpha }\end{array}$ & Mean & SD \\
\hline CETSCALE & 17 & .797 & 62.531 & 1.0044 \\
\hline Attitudes Scale & 06 & .802 & 20.213 & 1.9481 \\
\hline
\end{tabular}

According to the descriptive statistics given in the table 1, CE level of Czech customers is at a moderate level $(\mathrm{M}=62.531, \mathrm{SD}=1.004)$. Furthermore, the customer favorable attitude towards foreign beers was also at a moderate level $(\mathrm{M}=20.213, \mathrm{SD}=1.9481)$. In addition to descriptive statistics, the researchers assessed the ethnocentric tendency of customers by using principal components analysis (PCA) and a varimax rotation method with the purpose of identifying the main aspects of consumer ethnocentric tendencies in Czech consumers. Accordingly, the individual items of CETSCALE were grouped into four factors based on 
Eigen values and dip in the scree plot. One or more Eigen values are selected as a criterion in determining the number of factors to be extracted.

According to the PCA analysis, each item of CETSCALE was loaded to four different factors (see table 2) and the total variance of the four factor solutions for CE was 81.04. Factor 01 has high coefficients for six variables of the CETSCALE model (CE1, CE4, CE5, CE7, CE9, and CE13). Each variable reflects the consumers' love for or devotion to Czech or the pride of their nation. Based on the definition given by Sharma et al., (1995), Factor 01 was labeled as patriotism of customers. Factor 2 highly relates to five variables: CE3, CE6, CE8, CE11, and CE17. Those factors are directly related to consumer feelings to buy domestic brands due to the negative impacts of foreign products to the local economy and employment. Based on the CETSCALE validation by Lindquist, Vida, Plank \& Fairhurst (2001), this factor may be labeled as the feeling of bad economic and employment impact. Factor 3 highly relates to 03 variables (CE2, CE10, and CE16) which make an appeal to consumers to buy foreign brands when domestic products are not available. So accordingly, this factor may be labeled as product availability. The fourth and last factor has high coefficients for CE12, CE14 and CE15 and these variables reflect the customers fear, hate or animosity towards foreign products. Consequently, this factor may be labeled xenophobia. Based on researchers' labeling of these factors, consumer ethnocentrism of Czech consumers will be determined by four aspects named 1) patriotism, 2) the feeling of bad economic and employment impact, 3) product availability and 4) xenophobia.

Tab. 2 - Rotated Component Matrix. Source: Survey data 2011

\begin{tabular}{|c|c|c|c|c|}
\hline & \multicolumn{4}{|c|}{ Component } \\
\hline & 1 & 2 & 3 & 4 \\
\hline $\begin{array}{l}\text { CE1 - Czech citizens should always buy Czech- made prod- } \\
\text { ucts instead of imports }\end{array}$ & .725 & & & \\
\hline CE4 - Czech products, first, last, and foremost & .684 & & & \\
\hline CE5 - Purchasing foreign-made products is un-Czech & .807 & & & \\
\hline CE7 - A real Czech should always buy Czech- made products & .884 & & & \\
\hline CE9 - It is always best to purchase Czech- made products & .851 & & & \\
\hline $\begin{array}{l}\text { CE13 - It may cost me in the long run but I prefer to support } \\
\text { Czech products }\end{array}$ & .807 & & & \\
\hline $\begin{array}{l}\text { CE3- Buy Czech- made products. Keep Czech Republic } \\
\text { working }\end{array}$ & & .883 & & \\
\hline $\begin{array}{l}\text { CE6 - It is not right to purchase foreign products, because it } \\
\text { puts Czechs out of a job }\end{array}$ & & .705 & & \\
\hline $\begin{array}{l}\text { CE8 - We should purchase products manufactured in the } \\
\text { Czech Republic instead of letting other countries get rich } \\
\text { from us }\end{array}$ & & .953 & & \\
\hline
\end{tabular}




\begin{tabular}{|c|c|c|c|}
\hline $\begin{array}{l}\text { CE11 - Czechs should not buy foreign products, because this } \\
\text { hurts Czech businesses and causes unemployment }\end{array}$ & .815 & & \\
\hline $\begin{array}{c}\text { CE17 - Czech consumers who purchase products made in } \\
\text { other countries are responsible for putting their fellow Czechs } \\
\text { out of work }\end{array}$ & .608 & & \\
\hline $\begin{array}{l}\text { CE2 - Only those products that are unavailable in Czech } \\
\text { Republic should be imported }\end{array}$ & & .610 & \\
\hline $\begin{array}{l}\text { CE10 - There should be very little trading or purchasing of } \\
\text { goods from other countries unless out of necessity }\end{array}$ & & .766 & \\
\hline $\begin{array}{l}\text { CE16 - We should buy from foreign countries only those } \\
\text { products that we cannot obtain within our own country }\end{array}$ & & .748 & \\
\hline CE12 - Curbs should be put on all imports & & & .712 \\
\hline $\begin{array}{l}\text { CE14 - Foreigners should not be allowed to put their products } \\
\text { in our markets }\end{array}$ & & & .637 \\
\hline $\begin{array}{l}\text { CE15 - Foreign products should be taxed heavily to reduce } \\
\text { their entry into the Czech Republic }\end{array}$ & & & .551 \\
\hline
\end{tabular}

Extraction Method: Principal Component Analysis. Rotation Method: Varimax with Kaiser Normalization. a. Rotation converged in 7 iterations.

The attitudes towards foreign beer brands were assessed based on six dimensions: price, quality, taste, aroma, alcohol containment and health impact. According to the descriptive statistics (table 1), overall favorable attitudes (based on aggregate values) towards foreign brands was at a moderate level. However, Pearson correlation analysis was conducted in order to examine the relationship between the overall attitudes and the four aspects of CE suggested by PCA analysis (See table 3). The findings revealed that each aspect of the CE has a negative correlation with consumer favorable attitudes towards foreign beer brands. The highest correlation coefficient $(r=-0.285)$ was reported between consumer attitudes and the patriotism aspect of $\mathrm{CE}$ and it was significant at 0.01 levels (2-tailed).

Tab 3 - Correlation Matrix. Source: Survey data 2011

\begin{tabular}{|c|c|c|c|c|c|}
\hline & $\begin{array}{c}\text { Patriot- } \\
\text { ism }\end{array}$ & $\begin{array}{c}\text { Economic } \\
\text { and em- } \\
\text { ployment } \\
\text { Impact }\end{array}$ & $\begin{array}{c}\text { Product } \\
\text { availabil- } \\
\text { ity }\end{array}$ & $\begin{array}{c}\text { Xenopho- } \\
\text { bia }\end{array}$ & $\begin{array}{c}\text { Overall } \\
\text { attitude }\end{array}$ \\
\hline Patriotism & 1.000 & & & & \\
\hline $\begin{array}{c}\text { Feeling of bad Economic } \\
\text { \& employment impact }\end{array}$ & $.751^{* *}$ & 1.000 & & & \\
\hline Product availability & $.761^{* *}$ & $.892^{* *}$ & 1.000 & & \\
\hline Xenophobia & $.542^{* *}$ & $.770^{* *}$ & $.781^{* *}$ & 1.000 & \\
\hline Overall attitude & $-.285^{* *}$ & $-.237^{*}$ & -.148 & -.143 & 1.000 \\
\hline
\end{tabular}


Further findings indicated that the other three aspects of CE also have a significant negative correlation with consumer attitudes towards foreign beer brands. Therefore H1 is supported by empirical evidence and it is concluded that the ethnocentric tendency of consumers may negatively correlate with the favorable attitudes of customers towards foreign beer brands in the Czech Republic. Further findings have revealed that each aspect of CE has significant positive correlations among themselves.

A multiple regression analysis was conducted to predict the degree to which CE dimensions influence the attitudes of customers. Four factors of CE discovered from PCA analysis were entered simultaneously into the analysis. The overall variance explained by the four predictors of Czech consumers' attitudes towards foreign brands was $12.3 \%$ (based on R Square).

Tab. 4 - Regression models on CE aspects and Attitudes. Source: Survey data 2011

\begin{tabular}{|c|c|}
\hline Explanatory variable & $\begin{array}{c}\beta \text { value }- \text { Overall } \\
\text { Attitudes }\end{array}$ \\
\hline Constant & $22.782^{\mathrm{a}}(27.728)$ \\
\hline F1- Patriotism & $-.351^{\mathrm{a}}(-1.681)$ \\
\hline F2- Feeling of bad economic \& employment impact & $-.372^{\mathrm{a}}(-2.344)$ \\
\hline F3- Product availability &.$- .087(-0.715)$ \\
\hline F4 - Xenophobia & $-.047(-.298)$ \\
\hline R Square & .123 \\
\hline Adjusted R Square & .089 \\
\hline F-statistics & 3.603 \\
\hline Sig. & $.000 \mathrm{a}$ \\
\hline Number of observations & 108 \\
\hline
\end{tabular}

Note: Figures within parentheses are t-test results. a, denote significance at 0.01 level. Statistics indicated that all the models do not have a collinearity problem and are free from heteroscedasticity.

Furthermore, the four aspects of CE negatively relate to the overall attitudes of customers towards foreign beer brands. As $\beta$ values and t statistics imply, judging from the strength of the influence of each independent variable on the customer overall attitudes towards foreign brands - feeling of bad economic \& employment impact, was the strongest explanatory variable with the largest standardized beta of -.372 and highest $t$ value of -2.344 . The next strongest explanatory variable with a beta of -.351 and a $t$ value of -1.681 was the patriotic tendency of customers. The findings further revealed that the other two aspects of $\mathrm{CE}$ are not significant explanatory variables on consumer attitudes. Therefore it was evident that the Czech consumers are more ethnocentric due to the negative impact of foreign products on their local economy as well as the patriotic feelings about the mother nation.

Hypothesis two asserts that high-ethnocentricity consumers will have less favorable attitudes towards foreign beer brands than those with lower levels of ethnocentrism. An independent t- test was conducted by dividing the total sample into high ethnocentric and low ethnocentric 
consumers with the purpose of testing this hypothesis. High ethnocentric customers were identified as customers who have taken more than a 50\% score on the CESTCALE items. The results are given in table 5 and 6 .

Tab. 5 - Group Statistics. Source: Survey data 2011

\begin{tabular}{|c|c|c|c|c|c|}
\hline & $\begin{array}{c}\text { Level of } \\
\text { Ethno }\end{array}$ & N & Mean & $\begin{array}{c}\text { Std. } \\
\text { Deviation }\end{array}$ & $\begin{array}{c}\text { Std. Error } \\
\text { Mean }\end{array}$ \\
\hline \multirow{2}{*}{ Total attitude } & High & 60 & 19.7833 & 2.38705 & .30817 \\
\cline { 2 - 6 } & Low & 48 & 20.7500 & .97849 & .14123 \\
\hline
\end{tabular}

Tab. 6 - Independent t Test. Source: Survey data 2011

\begin{tabular}{|c|c|c|c|c|c|c|c|c|c|c|}
\hline & \multicolumn{2}{|c|}{$\begin{array}{c}\text { Levene's Test } \\
\text { for Equality of } \\
\text { Variances }\end{array}$} & \multicolumn{7}{|c|}{ t-test for Equality of Means } \\
\hline & & \multirow[t]{2}{*}{ F. } & \multirow[t]{2}{*}{ Sig } & \multirow[t]{2}{*}{$\mathrm{t}$} & \multirow[t]{2}{*}{ df } & \multirow{2}{*}{$\begin{array}{l}\text { Sig. } \\
(2- \\
\text { tailed })\end{array}$} & \multirow{2}{*}{$\begin{array}{l}\text { Mean } \\
\text { Differ- } \\
\text { ence }\end{array}$} & \multirow{2}{*}{$\begin{array}{l}\text { Std. } \\
\text { Error } \\
\text { Differ- } \\
\text { ence }\end{array}$} & \multicolumn{2}{|c|}{$\begin{array}{l}95 \% \text { Confidence } \\
\text { Interval of the Dif } \\
\text { ference }\end{array}$} \\
\hline & & & & & & & & & Lower & Upper \\
\hline 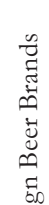 & 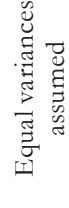 & 21.519 & .000 & -2.632 & 106 & .010 & -.96667 & .36722 & -1.69472 & -.23861 \\
\hline 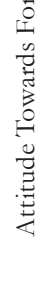 & 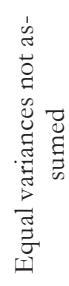 & & & -2.852 & 81.854 & .006 & -.96667 & .33899 & -1.64104 & -.29229 \\
\hline
\end{tabular}

According to the independent t- test group statistics given in Table 05, there is a difference between favourable attitudes towards foreign brands of high ethnocentric consumers $(\mathrm{M}=$ $19.78, \mathrm{SD}=2.38)$ and low ethnocentric consumers $(\mathrm{M}=20.75, \mathrm{SD}=.978)$. Therefore the findings revealed that the mean value relevant to high ethnocentric customers is greater than their counterparts. Furthermore, the results given in table 6 revealed that the statistical significance of the difference in the mean values seemed to be significant. Levene's Test P value of attitudes towards foreign brands is .000 ( $>$ > .05). Therefore $\mathrm{H} 2$ is completely supported. It is implied that high-ethnocentric Czech consumers will have less favorable attitudes towards foreign beer brands than low ethnocentric customers.

Hypothesis three has demonstrated that the relationship between demographic variables and ethnocentrism. One way analysis of variance (ANOVA) was carried out with the purpose of 
testing whether there is a significant difference between age, gender, income and education (demographic characteristics) of Czech consumers and their degree of ethnocentrism. According to the results in table 7 , there is no significant differences across age $(F=2.185, p>0.05)$ and gender $(\mathrm{F}=3.581, \mathrm{p}>0.05)$. However, there is a significant difference across income $(\mathrm{F}=$ 39.517, $\mathrm{p}<0.001)$ and education $(\mathrm{F}=54.216, \mathrm{p}<0.001)$. Furthermore, a Turkey Post-hoc Test revealed that the low income category $(8000 \mathrm{CZK}-15000 \mathrm{CZK})$, displays a high degree of ethnocentrism compared to other higher income groups. Moreover, inadequately educated people become more ethnocentric compared to highly educated people in the Czech Republic. Therefore, H3 was not fully supported by the empirical evidence.

Tab. 7 - Analysis of variance results (ANOVA). Survey data 2011

\begin{tabular}{|c|c|c|c|c|c|}
\hline & $\begin{array}{c}\text { Sum of } \\
\text { Squares }\end{array}$ & df & $\begin{array}{c}\text { Mean } \\
\text { Square }\end{array}$ & F & Sig. \\
\hline Age & 551.652 & 2 & 275.826 & 2.185 & .118 \\
\hline Gender & 451.226 & 1 & 451.226 & 3.581 & .061 \\
\hline Income & 7355.949 & 3 & 2451.983 & $39.517 *$ & .000 \\
\hline Education & 7015.552 & 2 & 3507.776 & $54.216^{*}$ & .000 \\
\hline
\end{tabular}

Notes: ${ }^{*} \mathrm{p}<0.001$

\section{DISCUSSION OF RESULTS}

According to the empirical results given in above section, ethnocentric tendencies of Czech customers represent in four psychological aspects such as patriotism, the feeling of bad economic and employment impact, product availability and xenophobia. On the other wards, Czech customers may stimulate to buy the Czech beers due to aforesaid reasons. Further results of correlation analysis revealed that all the psychological aspects are negatively correlated with consumer favorable attitudes towards foreign beer brands. It revealed that the ethnocentric tendency of consumers may negatively correlate with the favorable attitudes of customers towards foreign beer brands in the Czech Republic. According to the previous studies CE resulted in negative attitudes against foreign products. Further there are many empirical supports given for a positive relationship between $\mathrm{CE}$ and purchase intention of domestic products and the direct negative link between CE and willingness to buy foreign products. Therefore the findings of present study are confirmed with the previous findings of respective field. On the other wards general principles associated with CE is applicable to Czech customers as well.

Furthermore each aspect of ethnocentric tendency has positive correlation with each other. This finding indicated that even though Czech customers are motivating to buy local beer brands based on four aspects of CE, each aspect closely associated with the ethnocentric tendency prevailing in their minds. Therefore it confirms with the theory introduced by Shimp \& Sharma in 1987. As per the results given in multiple regression analysis, Czech customers staying in Zlin region are motivated to buy local beer brands due to the feeling of bad impact made by foreign beer companies to the economy and employment of Czech Republic. Further empirical results revealed that a patriotic feeling of Czech customers towards the mother nation 
is also important factor of generating customer ethnocentric tendency. However customers do not show the considerable degree of xenophobia and may not encourage for selecting foreign beer brands due to local alternatives are unavailable in the domestic market. These findings further revealed that Czech customers are maintaining high degree of cultural openness and willing to associate with the people in other countries. Furthermore sufficient number of domestic beer brands is available in the local market compared to foreign counterparts. According to the results given in independent $t$ test, high ethnocentric customers show less favorable attitudes towards foreign beer brands than low ethnocentric customers. Some previous studies noted that young mail customers are less ethnocentric compared to other age and gender groups. However the findings of present study further reveal that there are no significant differences between CE and some demographic factors, mainly age and gender. It further reveals that Czech customers are maintaining ethnocentric tendency irrespective to their age and gender. However, both education level and income level negatively correlated to CE. Therefore, low income and less educated consumers seem to be more ethnocentric. On the other wards, educated well off Czech customers are maintaining high degree of cultural openness and willing to buy foreign beer brands without considering country of origin.

\section{CONCLUSION}

The present study has been mainly focused on investigating the ethnocentric tendency of Czech customers and their attitude towards foreign beer brands available in their local market. The empirical evidences support the first two hypotheses and reject the third hypothesis. Therefore it reveals that the ethnocentric tendency of consumers may negatively correlate to the favorable attitudes of customers towards foreign beer brands in the Czech Republic and that highly ethnocentric customers hold less favorable attitudes towards those foreign brands. Further empirical evidence concluded that there is no strong relationship between each demographic variable and CE within Czech customers. Therefore the findings are confirmed with the previous research evidence and theories. The results of the study offer some implications to the domestic brewery companies in the Czech Republic to rethink about their current strategies. In practical scenarios, most of the local brands are performing well in the domestic market. However they cannot under-value the increasing threat of foreign competitors. Therefore, marketers of local brewery companies should use ethnocentric brand appeals associated with the Czech beer culture to attract more customers in growing segments. Furthermore, they can use the findings of the study in segmentation and positioning of their beer brands in the domestic market.

This study was characterized by several limitations that restrict the reliability to generalize the findings. First, the study was restricted to the Zlin region in the Czech Republic. As the Zlin region represents South-East Moravia, it may be possible to obtain different results in the case of conducting the study in other parts of the Czech Republic. Furthermore, the data was collected from students of TBU with using self administrated questionnaires. Thus it is possible that these respondents may have provided highly subjective responses and also the entire population of the Zlin region may not be represented by them. Therefore further research can be designed to investigate this issue in different areas of the Czech Republic; using random or 
stratified sampling techniques to represent the total population in the Czech Republic. Furthermore, future researches could investigate the impact of customer attitudes in considering the country of origin of the beer brands as well.

\section{References}

1. Adorno, T. W., Frenkel-Brunswik, E., Levinson, D. J., \& Sanford, R. N. (1950). The authoritarian personality. NY: Harper \& Row.

2. Akaah, I. P., \& Yaprak, A. (1993). Assessing the influence of country of origin on product evaluation: an application of conjoint methodology. Journal of International Consumer Marketing, 5(2), 39-53. http://dx.doi.org/10.1300/J046v05n02_04.

3. Akram, A., Merunka, D., \& Akram, M. S. (2011). Perceived brand globalness in emerging markets and the moderating role of consumer ethnocentrism. International Journal of Emerging Markets, 6(4), 291-303. http://dx.doi.org/10.1108/17468801111170329.

4. Balabanis, G., Diamantopoulos, A., Mueller, R. D., \& Melewar, T. C. (2001). The impact of nationalism, patriotism and internationalism on consumer ethnocentric tendencies. Journal of International Business Studies, 32(1), 157- 175. Retrieved from http://ehis.ebscohost.com/

5. Biljana, J., \& Anthony, W. (1998). Consumers' attitudes towards imported food products. Food Quality and Preference, 9(6), 431-441. http://dx.doi.org/10.1016/S0950-3293(98)00027-5.

6. Caruana, A., \& Magri, E. (1996). The effects of dogmatism and social class variables on consumer ethnocentrism in Malta. Marketing Intelligence and Planning, 14(4), 39 - 44. http://dx.doi. org $/ 10.1108 / 02634509610121569$.

7. Damisch, P. "Consumer patriotism in Central and Eastern Europe - is it true in daily life?", Towards a Market Economy: Beyond the Point of No Return, Second East and Central European Conference, ESOMAR, Warsaw. April 1995.

8. Erdogan, B. Z., \& Uzkurt, C. (2010). Effects of ethnocentric tendency on consumers' perception of product attitudes for foreign and domestic products. Cross Cultural Management: An International Journal, 17(4), 393-406. http://dx.doi.org/10.1108/13527601011086595.

9. Ettenson, R., Wagner, J., \& Gaeth, G. (1988). Evaluating the effect of country of origin and the 'made in the usa' campaign: a conjoint approach. Journal of Retailing, 64(1), 85-100. Retrieved from http://ehis.ebscohost.com/

10. Euromonitor, (2010). Beer in the Czech Republic. Retrieved from website: http://www.marketresearch.com/Euromonitor-International-v746/Beer-Czech-Republic-2591326/

11. George, D., \& Mallery, P. (2003). SPSS for Windows step by step: A simple guide and reference. 11.0 update (4th ed.). Boston: Allyn \& Bacon.

12. Gibbs, J. and Boguszak, M. (1995), “Open market aftershocks: Czech and Slovak attitude toward brands", Towards a Market Economy: Beyond the Point of No Return, Second East and Central European Conference, ESOMAR, Warsaw, April 1995.

13. Good, L. K., \& Huddleston, P. (1995). Ethnocentrism of polish and russian consumers: are feelings and intentions related?. International Marketing Review, 12(5), 35-48. http://dx.doi. org $/ 10.1108 / 02651339510103047$. 
14. Huddleston, P., Linda, K., \& Lesli, S. (2001). Consumer ethnocentrism, product and polish consumers' perceptions of quality. International Journal of Retail and Distribution Management, 29(5), 236-246. http://dx.doi.org/10.1108/09590550110390896.

15. Javalgi, R. G., Khare, V. P., Gross, A. C., \& Scherer, R. F. (2005). An application of the consumer ethnocentrism model to french consumers. International Business Review, 14, 325 - 344. http://dx.doi.org/10.1016/j.ibusrev.2004.12.006

16. Juric, B., Worsley, T. and Garrett, T. "Towards a Model of Consumers' Attitudes to Foreign versus Local Food Products," Proceedings of the 10 $0^{\text {th }}$ Australian Marketing Educators' Conference, Adelaide. February 1996.

17. Kaynak, E., \& Cavusgil, S. (1983). Consumer attitudes towards products of foreign origin: do they vary across product classes?. International Journal of Advertising, 2, 147-157.

18. Kaynak, E., \& Kara, A. (2002). Consumer perceptions of foreign products. European Journal of Marketing, 36(7/8), 928 - 949. http://dx.doi.org/10.1108/03090560210430881.

19. Klein, J. G., \& Ettenson, R. (1999). Consumer animosity and consumer ethnocentrism: an analysis of unique antecedents. Journal of International Consumer Marketing, 11(4), 5. Retrieved from http://search.proquest.com/

20. Klein, J. G., Ettenson, R., \& Krishnan, B. C. (2006). Extending the construct of consumer ethnocentrism: when foreign products are preferred. International Marketing Review, 23(3), 304 321. http://dx.doi.org/10.1108/02651330610670460

21. Klenosky, D. B., Benet, S. B., \& Chatraba, P. (1996). Assessing czech consumers' reactions to western marketing practices: a conjoint approach. Journal of Business Research, 36(2), 189 - 198. http://dx.doi.org/10.1016/0148-2963(95)00121-2

22. Kwak, H., Jaju, A., \& Larson, T. (2006). Consumer ethnocentrism offline and online: themediating role of marketing efforts and personality traits in the united states, south korea, and india. Journal of the Academy of Marketing Science, 34(3), 367-385. Retrieved from http://ehis. ebscohost.com/

23. Lantz, G., \& Loeb, S. (1996). Country of origin and ethnocentrism: an analysis of Canadian and American preferences using social identity theory. Advances in Consumer Research, 23, 374378. Retrieved from http://ehis.ebscohost.com/

24. Lee, W., Hong, J., \& Lee, S. (2003). Communicating with American consumers in the post 9/11 climate: An empirical investigation of consumer ethnocentrism in the United States. International Journal of Advertising, 22, 487-510. Retrieved from http://ehis.ebscohost.com/

25. Levine,, R. A., \& Campbell, D. T. (1972). Ethnocentrism: Theories of conflict, ethnic attitudes, and group behavior. NY: Wiley.

26. Lindquist, J. D., Vida, I., Plank, R., \& Fairhurst, A. (2001). The modified cetscale: validity tests in the czech republic, hungary and poland. International Business Review, 10(5), 505-516. http://dx.doi.org/10.1016/S0969-5931(01)00030-0.

27. Luque-Martinez, T., Ibanez-Zapata, J. A., \& Barrio-Garcia, S. (2000). Consumer ethnocentrism measurement:an assessment of the reliability and validity of the CETSCALE in Spain. European Journal of Marketing, 34(11/12), 1353-1373. http://dx.doi.org/10.1108/03090560010 348498. 
28. McLain, S., \& Sternquist, B. (1991). Ethnocentric consumers: do they buy American?. Journal of International Consumer Marketing, 4(1/2), 39-57.

29. Netemeyer. , Richard, G., Durvasula, S., Lichtenstein, , \& Donald, R. (1991). A cross national assessment of the reliability and validity of the CETSCALE. Journal of Marketing Research, 28(3), 320 - 327. Retrieved from http://ehis.ebscohost.com/

30. Papadopoulos, N., Heslop, L. A., \& Beracs, J. (1990). National stereotypes and product evaluations in a socialist country. International Marketing Review, 7(1), 32 - 47. http://dx.doi. org $/ 10.1108 / 02651339010141365$

31. Sajdakowska, M. (2003). Consumer ethnocentrism . factor influencing consumers. purchasing decisions in the food market. Acta Scientiarum Polonorum, Technologia Alimentaria, 2(1), 177.

32. Schooler, R. D. (1971). Bias phenomena attendant to the marketing of foreign goods in the us. Journal of International Business Studies, 2, 71-80. Retrieved from http://www.jstor.org/

33. Shamindra, N. S., \& Datta, S. K. (2011). The effect of country of origin on brand equity: an empirical study on generic drugs. Journal of Product \& Brand Management, 20(2), 130-140. http://dx.doi.org/ 10.1108/10610421111121125.

34. Shankarmahesh, M. N. (2006). Consumer ethnocentrism: an integrative review of its antecedents and consequences. International Marketing Review, 23(2), 146-172. http://dx.doi.org/10 $.1108 / 02651330610660065$.

35. Sharma, S., Shimp, T. A., \& Shin, J. (1995). Consumer ethnocentrism: a test of antecedents and moderators. Journal of the Academy of Marketing Science, 23(1), 26 - 37. Retrieved from http:// ehis.ebscohost.com/

36. Shimp, T., \& Sharma, S. (1987). Consumer ethnocentrism: construction and validation of the cetscale. Journal of Marketing Research, 14, 280 - 289. Retrieved from http://jstor.org

37. Siemieniako, D., Kubacki, K., Glin'ska, E., \& Krot, K. (2011). National and regional ethnocentrism: a case study of beer consumers in poland. British Food Journal, 113(3), 404 - 418. http://dx.doi.org/10.1108/00070701111116464.

38. Sumner, W. G. (1906). Folkways: The sociological importance of usages, manners, customs, mores, and morals. NY: Harper \& Row.

39. Supphellen, M., \& Grønhaug, K. (2003). Building foreign brand personalities in Russia: the moderating effect of consumer ethnocentrism. International Journal of Advertising, 22, 203 226. Retrieved from http://ehis.ebscohost.com/

40. Vida, I., \& Fairhurst, A. (1999). Factors underlying the phenomenon of consumer ethnocentricity: evidence from four central european countries. International Review of Retail, Distribution, and Consumer Research, 9(4), 321 -337. Retrieved from http://ehis.ebscohost.com/

41. Vida, I., Dmitrovic', T., \& Obadia, C. (2008). The role of ethnic affiliation in consumer ethnocentrism. European Journal of Marketing, 42(3/4), 327 - 343. http://dx.doi.org/10.1108/0 3090560810852968

42. Wall, M., \& Heslop, L. A. (1986). Consumer attitudes towards the quality of domestic and imported apparel and footwear. Journal of the Academy of Marketing Science, 14(2), 27-36. http:// dx.doi.org/ 10.1111/j.1470-6431.1989.tb00029.x 
43. Wanninayake W.M.C.B, Dissanayake D.M.R, "Impact of Developing Ethnocentric Brand Templates to Sustain the Local Brands-An Empirical Study", International Conference of Business Management (ICBM), University of Sri Jayawardanapura, Sri Lanka. March 2009.

44. Watson, J. J., \& Wright, K. (2000). Consumer ethnocentrism and attitude toward domestic and foreign products. European Journal of Marketing, 34(9/10), 11 - 49. http://dx.doi.org/ $10.1108 / 03090560010342520$

\section{Contact information}

W.M.C.Bandara Wanninayake

Tomas Bata University in Zlin, Faculty of Management and Economics

Mostni 513976001 Zlin

University of Kelaniya, Sri Lanka

E-mail:bwanninayake@gmail.com

Miloslava Chovancová, PhD.

Associate Professor

Tomas Bata University in Zlin, Faculty of Management and Economics

Mostni 513976001 Zlin

E-mail:chovancova@fame.utb.cr. 